\title{
Dinophysis - a planktonic dinoflagellate genus which can act both as a prey and a predator of a ciliate
}

\author{
Per Juel Hansen
}

Marine Biological Laboratory, University of Copenhagen, Strandpromenaden 5, DK-3000 Helsingør, Denmark

\begin{abstract}
Heterotrophic members of the marine plankton dinoflagellate genus Dinophysis are specialized predators, whose food includes the prostomatid ciliate Tiarina fusus. This ciliate differs from most planktonic ciliates in its ability to ingest prey of its own size including autotrophic Dinophysis spp. However, when trying to catch a heterotrophic Dinophysis sp., the ciliate is trapped instead by the dinoflagellate and emptied via a feeding tube (peduncle), which originates from the flagellar pore of the dinoflagellate. The specific predation on a ciliate by a heterotrophic dinoflagellate represents a new trophic link in the marine planktonic food web.
\end{abstract}

The existence of colourless thecate dinoflagellates in the marine pelagial has been recognized among taxonomists for more than a century (Gaines \& Elbrächter 1987). In spite of this, few ecological studies dealing with the marine planktonic food webs have included them in the protozoan plankton even though they may make up a substantial part of the biomass of this group (Smetacek 1981). Knowledge about their trophic role in the marine pelagial has simply been too poor.

Recent studies have revealed that a number of colourless thecate species belonging to the genera Protoperidinium, Oblea and Zygabikodinium are able to feed on large diatoms and dinoflagellates by a pseudopodium, a 'feeding veil' or a 'pallium', which encloses the prey (Gaines \& Taylor 1984, Jacobson \& Anderson 1986). The species studied so far all belong to the order Peridinales.

The purpose of this work has been to study the trophic role and feeding mechanism of colourless species belonging to the order Dinophysiales.

Materials and Methods. Samples of surface water were collected from a permanent station in the southern part of Kattegat $\left(56^{\circ} 15.42 \mathrm{E}, 12^{\circ} 00.12 \mathrm{~N}\right)$, Denmark, during 1989. The plankton was concentrated (net mesh size $20 \mu \mathrm{m}$ ) and incubated in $65 \mathrm{ml}$ tissue culture flasks
(Nunclon, Denmark) at low light $\left(50 \mu \mathrm{E} \mathrm{m}^{-2} \mathrm{~s}^{-1}\right)$ on a rotating wheel at $18 \pm 1{ }^{\circ} \mathrm{C}$. The feeding behaviour of heterotrophic (colourless) Dinophysis and the nature of food items were studied microscopically. For enumeration of plankton, Lugol-fixed water samples (at least $50 \mathrm{ml}$ ) were allowed to settle, and counted using an inverted microscope. For transmission electron microscopy, cells were fixed in a $0.1 \mathrm{M}$ phosphate buffer $(\mathrm{pH}$ 7.5) with $1 \% \mathrm{OsO}_{4}, 3 \%$ glutaraldehyde and $1 \mathrm{mM}$ sucrose. The fixed cells were stained in a saturated solution of uranyl acetate in $70 \%$ ethanol for $1 \mathrm{~h}$, dehydrated and imbedded in Epon. Sections were made with an LKB ultratone and viewed with a Zeiss EM9 electron microscope.

Results and discussion. Microscopical observations of a large number of incubated samples from late summer and autumn (21 Aug to 23 Nov 1989) revealed that Dinophysis rotundata (Claparéde \& Lachmann) and $D$. hastata (Stein) were able to feed on the prostomatid ciliate Tiarina fusus (Clap. \& Lach.).

Tiarina differs from most pelagic ciliates (e.g. tintinnids and oligotrichs) in the ability to ingest prey of approximately its own size including autotrophic Dinophysis spp. This is due to the flexible cytostome of this ciliate. When trying to catch and ingest heterotrophic Dinophysis species like D. rotundata or D. hastata, however, the roles are changed: the ciliate becomes the prey and the dinoflagellate the predator. The ciliate is trapped, presumably by extrusomes, and as it is the larger and faster-swimming of the two, the ciliate initially swims around with the Dinophysis attached to it. A pseudopodium subsequently extends from the flagellar pore of the dinoflagellate (Fig. 1), connecting the ciliate to the dinoflagellate. After a few minutes the ciliate becomes immobile and the dino- 

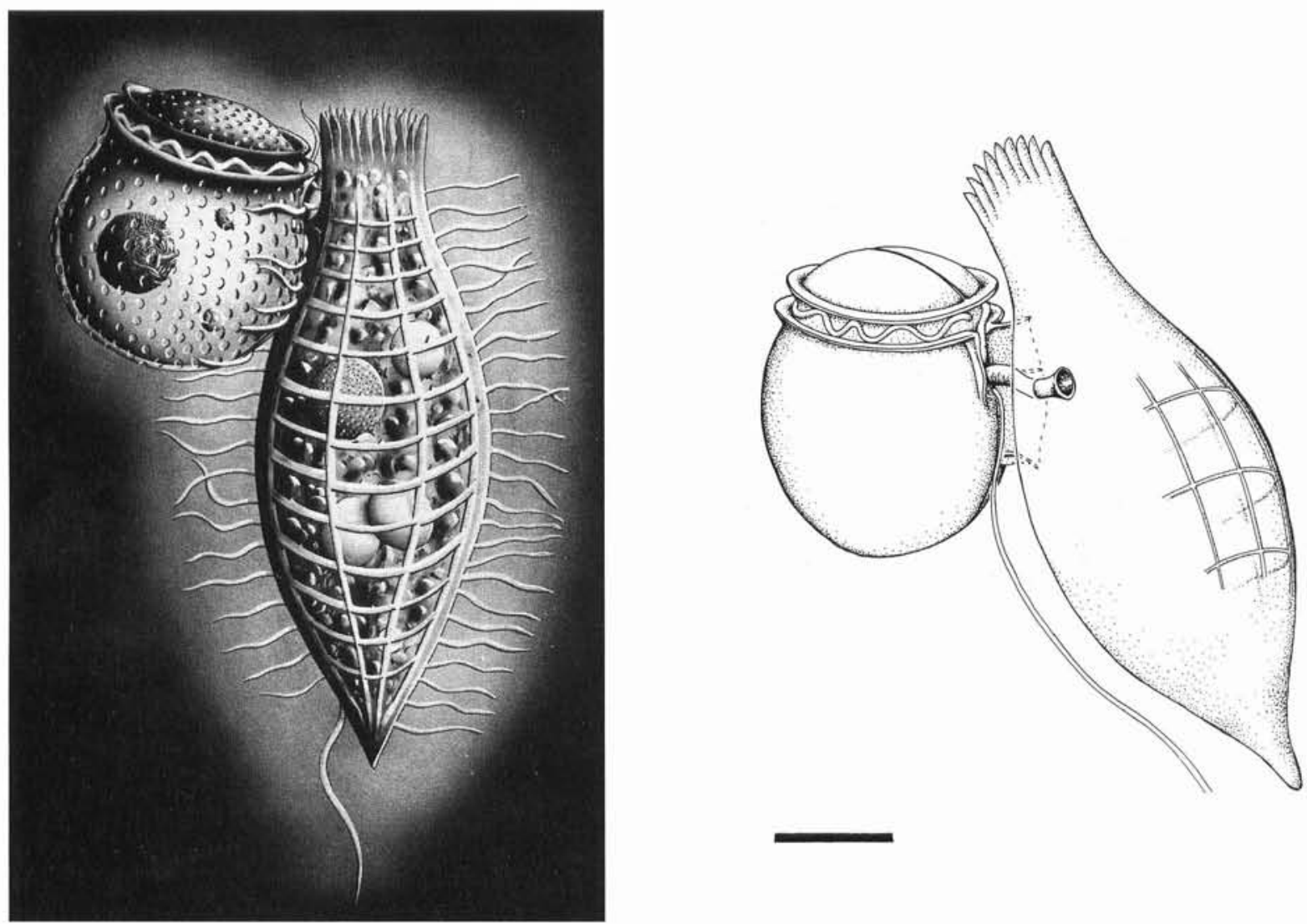

Fig. 1. The dinoflagellate Dinophysis rotundata feeding on the prostomatid ciliate Tiarina fusus. The ciliate has just been caught and the feeding tube (peduncle) connects the dinoflagellate with the ciliate. Schematic drawing to the right illustrates the physical connection between the dinoflagellate and the ciliate. The left sulcal list of the dinoflagellate is lying behind the ciliate. Scale bar $=20 \mu \mathrm{m}$

flagellate now swims around with the attached ciliate which it gradually consumes. The ciliate is often ingested from the anterior end, and when half of it is consumed its posterior end still retains its typical shape, although the cilia are shed. During the feeding process, which lasts about 2 to $3 \mathrm{~h}$, the dinoflagellate swells considerably, its cross section changing from a lenticular shape to an almost circular one. At this last stage the cell is filled with vacuoles containing prey cytoplasm.

The occurrence of heterotrophic Dinophysis spp. in the Kattegat during 1989 was largely restricted to the period August to December. Concentrations were within the range 20 to 320 cells $\mathrm{I}^{-1}$. D. rotundata was the dominating species although individuals of $D$. hastata were present in a few samples. The seasonal distribution of Tiarina fusus overlapped with that of heterotrophic Dinophysis spp. and they occurred in similar concentrations (range 20 to 540 cells $1^{-1}$ ). During this period the phytoplankton was dominated by dinoflagellates (Ceratium spp., Dinophysis spp., Prorocentrum spp.) and diatoms (Rhizosolenia spp., Chaetoceros spp.). In spite of this, D. rotundata was never observed to grow or prey on organisms other than $T$. fusus in the incubated net samples. I have managed to grow D. rotundata in $\mathrm{f} / 2$-medium (Guillard 1972) using $T$. fusus as food source. Cultures of $T$. fusus were based on the thecate dinoflagellate Heterocapsa triquetra as food.

The feeding behaviour of Dinophysis rotundata differs in several aspects from that of other marine thecate dinoflagellates. The precapture behaviour of 6 species of thecate dinoflagellates (belonging to the genera Protoperidinium, Oblea and Zygabikodinium) has recently been studied (Jacobson \& Anderson 1986). Typically, the dinoflagellate, when encountering a diatom, circles around the prey for up to $2 \mathrm{~min}$ prior to capture. This is not the case in Dinophysis since Tiarina swims much faster than the dinoflagellate. Instead the ciliate is trapped upon mechanical contact. A successful capture is related to the feeding state of the dinoflagellate, as further feeding was never observed in a Dinophysis which had just finished feeding.

The mechanism of food uptake also differs from that of other marine thecate heterotrophic dinoflagellates (Gaines \& Taylor 1984, Jacobson \& Anderson 1986). 

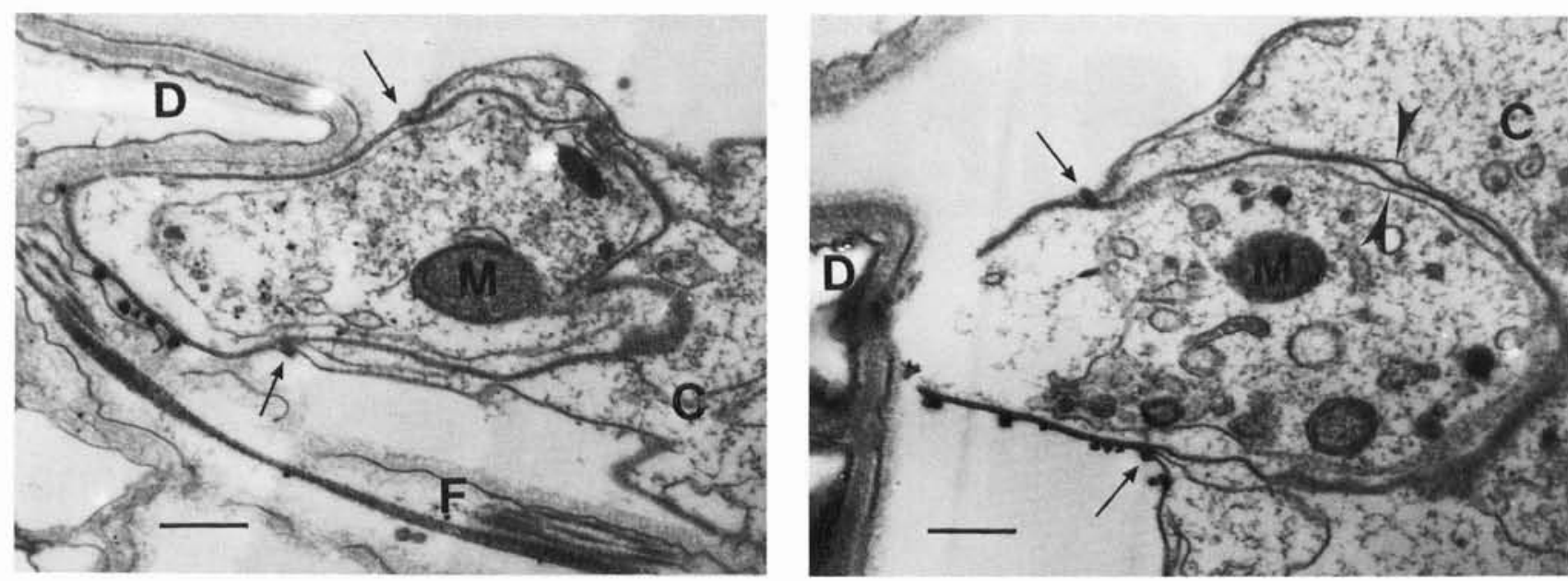

Fig. 2. Dinophysis rotundata ingesting Tiarina fusus. Transmission electron micrograph of the dinoflagellate feeding tube (peduncle). Left: Oblique cross section through the feeding tube as it leaves the dinoflagellate and enters the ciliate. Right: As left but a section of the feeding tube further inside the ciliate. C: Ciliate; D: dinoflagellate; F: dinoflagellate flagellum; M: ciliate mitochondrion; arrow: connection between the ciliate and the dinoflagellate membrane; arrow heads: membrane of the feeding tube enclosing a microtubular layer. Scale bar $=0.5 \mu \mathrm{m}$

The 'pallium' or 'feeding veil' enclosing the prey, which is easily observed in other thecate dinoflagellates, is absent in Dinophysis rotundata and D. hastata. Transmission electron microscopy studies reveal that the dinoflagellate pseudopodium pierces through the plasmalemma of the ciliate (Fig. 2). The ciliate cytoplasm is sucked up through a feeding tube similar to the 'peduncle' described for naked heterotrophic dinoflagellates like Gymnodinium fungiforme (Spero 1982), Paulsenella sp. (Schnepf et al. 1985) and Amphidinium poecilochroum (Larsen 1988). The peduncle contains a hollow cylinder of microtubules which is thought to be the extension of an internal microtubular basket (Lee 1977). Using the microtubular basket as a marker for the existence of a peduncle, a number of dinoflagellate species have been suggested to feed in this way, including photosynthetic species like Ceratium hirundinella and Prorocentrum micans, Prorocentrum mariae-lebouriae (Schnepf \& Winter 1990). During this study, photosynthetic Dinophysis species like $D$. acuta and $D$. norvegica were never observed to ingest anything at all. This is in agreement with Hallegraeff \& Lucas (1988) who examined 5 non-photosynthetic and 3 photosynthetic Dinophysis species by transmission electron microscopy. They found that only the colourless Dinophysis spp. contained food vacuoles.

Microbial food chains in the marine pelagial are currently believed to build on the principle of a more or less fixed size relationship between prey and predator of 1:10 (Azam et al. 1983). This study provides an example of 2 similarly sized species of the same dinoflagellate genus, which can act either as a prey or as a predator of a species of ciliate.
Acknowledgement. This study was supported by a grant from the Danish Environmental Protection Agency, grant no $2.03 \mathrm{~A}$. I am indebted to Tom Fenchel for encouraging discussions and to Tom Fenchel and Birgit L. Brander for help with TEM work. I thank Torkel Gissel Nielsen for the ciliate counts. I also thank Bent Vismann, who made the drawings, and Holger Knudsen for help with the photographical work.

\section{LITERATURE CITED}

Azam, F., Fenchel, T., Field, J. G., Gray, J. S., Meyer-Reil, L. A., Thingstad, F. (1983). The ecological role of watercolumn microbes in the sea. Mar. Ecol. Prog. Ser. 10: 257-263

Gaines, G., Elbrächter, M. (1987). Heterotrophic nutrition. In: Taylor, F. J. R. (ed.) Biology of dinoflagellates. Blackwell, Oxford, p. 224-268

Gaines, G., Taylor, F. J. R. (1984). Extracellular digestion in marine dinoflagellates. J. Plankton Res. 6: 1057-1061

Guillard, R. R. L. (1972). Culture of phytoplankton for feeding marine invertebrates. In: Smith, W. L., Chanley, M. H. (ed.) Culture of marine invertebrate animals. Plenum Press, New York, p. 29-60

Hallegraeff, G. M., Lucas, I. A. N. (1988). The marine dinoflagellate genus Dinophysis (Dinophyceae): photosynthetic, neritic and non-photosynthetic, oceanic species. Phycologia 27: 25-42

Jacobson, D. M., Anderson, D. M. (1986). Thecate heterotrophic dinoflagellates: feeding behaviour and mechanism. J. Phycol. 22: 249-258

Larsen, J. (1988). An ultrastructural study of Amphidinium poecilochroum (Dinophyceae), a phagotrophic dinoflagellate feeding on small species of cryptophytes. Phycologia 27: $366-377$

Lee, R. E. (1977). Saprophytic and phagotrophic isolates of the colourless heterotrophic dinoflagellate Gyrodinium lebouriae Herdman. J. mar. biol. Ass. U.K. 57: 303-315

Schnepf, E., Deichgräber, G., Drebes, G. (1985). Food uptake and the fine structure of the dinophyte 
Paulsenella sp., an ectoparasite of marine diatoms. Protoplasma 124: 188-204

Schnepf, E., Winter, S. (1990). A microtubular basket in the armoured dinoflagellate Prorocentrum micans (Dinophyceae). Arch. Protistenkd. 138: 89-91

This note was presented by Professor T. Fenchel, Helsingør, Denmark
Smetacek (1981). The annual cycle of protozooplankton in the Kiel Bight. Mar. Biol. 63: 1-11

Spero, H. J. (1982). Phagotrophy in Gymnodinium fungiforme (Pyrrhophyta): the peduncle as an organelle of ingestion. J. Phycol. 18: 356-360

Manuscript first received: July 11, 1990

Revised version accepted: October 18, 1990 